\title{
Effect of Irrigation Levels and Nitrogen Fertilizer Splitting on the Produc- tivity and Nitrogen Use Efficiency of Two Bread Wheat Cultivars
}

\author{
Teama, E.A.; A.H. Galal; E.A. Ali and Howida E. Abdelkader \\ Agronomy Dept., Fac. Agric., Assiut Univ., Egypt
}

Received on: 25/9/2016

Accepted for publication on: 27/9/2016

\begin{abstract}
This work was carried out during 2012/ 2013 and 2013/ 2014 seasons in the Agronomy Department Experimental Farm, Agriculture Faculty, Assiut University to study the effect of irrigation levels and nitrogen fertilizer splitting on the productivity and nitrogen use efficiency of two bread wheat cultivars. Three experiments each season were done. Each experiment was subjected to three irrigation levels (100, 75 and $50 \%$ of irrigation requirement). The experiment was laid out in Randomized Complete Block Design (RCBD) in split - plot arrangement with three replicates. Two treatments of nitrogen fertilizer splitting (2 and 4 times) were assigned in main - plots and the wheat cultivars (Giza-168 and Sids1) were arranged in sub-plots. The obtained results showed that studied irrigation levels, nitrogen fertilizer splitting and cultivars had a significant effect on all studied traits in the two growing seasons. Here too, the first and second order interactions had a significant influence on most studied traits in both seasons. Moreover, the highest mean values of grain yield (28.13 and $\left.28.02 \mathrm{ardab}^{-1} \mathrm{ded}^{-1}\right)$ and NUE (56.26 and $56.03 \mathrm{~kg}$ grain $/ \mathrm{kg} \mathrm{N}$ applied) in the first and second seasons, respectively were obtained from Sids-1 cultivar subjected to $I_{1}$ irrigation level and received nitrogen fertilizer at four splits.
\end{abstract}

Keywords: Irrigation levels, nitrogen fertilizer splitting, wheat cultivars, grain yield and NUE

\section{Introduction}

Wheat crop consider the most important cereal crops in the world with regard to cultivated area and total production. The cultivated area of wheat in Egypt during 2013 season was about 1418708 ha i.e.3377876 feddan with the total yield production of 9460200 ton (FAO, 2013). While the total consumption reached about 19600000 ton. So, increasing wheat production in order to reduce the gap between production and consumption are the strategic aim. High grain yield and good bread-making quality of wheat are opposite criteria and are influenced by the environmental conditions as well as by the irrigation, va- riety, $\mathrm{N}$-fertilization, and the interactions between these factors (Rao et al., 1993, Johansson et al., 2004 and Erekul et al., 2012).Water stress is the most important limitation to wheat productivity in semiarid regions of the world. Therefore, the development of the wheat cultivars that use available water more efficiently and that are able to tolerate drought is a major goal for increasing productivity in drought prone environments. Water deficit or drought has profound effects on wheat production in Egypt and worldwide. Water stress was found to significantly reduced grain yield and some agronomic traits of all studied cultivars. Cultivars were 
found to respond differently to water stress treatments. In general, drought sensitivity increases with increasing the intensity of water stress. Significant genotypic variations were observed among these durum wheat cultivars in water use efficiency (AlTabbal, 2011). Water deficit occurs when water potentials in the rhizosphere are sufficiently negative to reduce water availability to suboptimal levels for plant growth and development. Grain yield was affected by both the magnitude of water deficit and stage of growth subjected to deficit. Increasing irrigation amounts up to $100 \%$ of soil water significantly increased grain yield (Awad et al., 2000). Moisture stress is known to reduce biomass, tillering ability, grains per spike and grain size at any stage when it occurs. So, the overall effect of moisture stress depends on intensity and length of stress (Bukhat, 2005). Concerning nitrogen fertilizer splitting, In order to obtain high wheat yield and reduce potential NO-3 -N for leaching or other adverse environmental impacts, it is important to develop $\mathrm{N}$ management strategies to increase the $\mathrm{N}$ recovery fraction (NRF: $\mathrm{kg} \mathrm{N}$ uptake kg N applied_1) of applied N. Earlier $\mathrm{N}$ fertilizer application increases the risk of $\mathrm{N}$ loss from the root zone by leaching and denitrification. Therefore, the NRF of wheat is maximized when fertilizer is applied shortly before the period of most rapid crop $\mathrm{N}$ uptake (Howard et al. 2002), which occurs between early stem elongation and anthesis, the stage at which the crop can accumulate up to $75 \%$ of total $\mathrm{N}$ in above-ground biomass (NAB) at maturity. However, in environments with low water availability, $\mathrm{N}$ applications after stem elongation have been reported to reduce NRF and increased $\mathrm{N}$ use efficiency (Zebarth $e t$ al. 2007). Also, El-Agrodi et al. (2011) found that application of $\mathrm{N}$ in four splits recorded higher $\mathrm{N}$ percentage in whole wheat plants, straw and grains over application of $\mathrm{N}$ with two splits in $120 \mathrm{~kg} \mathrm{~N}$ per ha doses. Here too, Velasco et al. (2012) stated that in four out of six experiments, average $\mathrm{N}$ in above ground biomass (NAB), N recovery fraction (NRF), and grain protein content (GPC) for split $\mathrm{N}$ application were greater than for full $\mathrm{N}$ at $\mathrm{Z} 24$ (NAB, 176 and 157 $\mathrm{kg} \mathrm{N}$ ha_1; NRF, 66 and 51\%; GPC, 100 and $92 \mathrm{~g} \mathrm{~kg} 1$, for split and full $\mathrm{N}$ application, respectively). As shown by Debaeke et al. (1996) and Feil (1997) that yield and quality are negatively correlated. The objectives of this study were to determine the effect of irrigation water rationalization and nitrogen fertilizer splitting on the productivity and quality of some wheat cultivars.

\section{Materials and Methods}

This work was carried out during 2012/ 2013 and 2013/ 2014 seasons in the Agronomy Department Experimental Farm, Agriculture Faculty, Assiut University to study the effect of irrigation water rationalization and nitrogen fertilizer splitting on the productivity of two wheat cultivars. The mechanical and chemical analyses of the experimental sites of the soil are presented in Table 1. 
Table1. Some physical and chemical properties of experimental sites:

\begin{tabular}{|l|c|c|}
\hline \multicolumn{1}{|c|}{ Properties } & $\mathbf{2 0 1 2 / 2 0 1 3}$ & $\mathbf{2 0 1 3 / 2 0 1 4}$ \\
\hline Mechanical analysis: & 26.00 & 26.80 \\
Sand & 24.20 & 23.00 \\
Slit & 49.80 & 50.20 \\
Clay & Clay & Clay \\
Soil type & & \\
Chemical analysis: & 7.73 & 7.80 \\
pH & 1.74 & 1.62 \\
Organic matter \% & 0.08 & 0.07 \\
Total N\% & & \\
\hline
\end{tabular}

Three experiments each season were done. Each experiment was subjected to three irrigation levels $(100$, 75 and $50 \%$ of irrigation requirement i.e. $I 1=4000, \quad I 2=3000$ and $I 3=2000$ $\mathrm{m} 3 /$ fed-1, respectively). These amounts of irrigation water were recorded from the counter. The experiment was laid out in Randomized Complete Block Design (RCBD) in split - plot arrangement with three replicates. Two treatment of nitrogen fertilizer splitting (2 and 4 times) were assigned in main - plots and the wheat cultivars (Sids 1 and Giza 168) were arranged in sub-plots. Each subplot area was $10.5 \mathrm{~m} 2$. Wheat grains (Triticum aestivum L. c.v 'Sids- 1 and Giza-168) were sown by hand on 1 and 2 December in the first and second seasons, respectively. There commended dose of nitrogen fertilizer(75 kg fed -1 as a form of Urea, $46.5 \% \mathrm{~N})$ divided into two equal doses and add before second and third irrigation in the first splitting treatment ( 2 times), while, splitting into four equal doses (4 times) was added before the second, third, fourth and fifth irrigation. All other cultural practices that recommended for wheat crop were done in both seasons.
At harvest five guarded main stem for each sub-plot were taken and plant height $(\mathrm{cm})$, spike length $(\mathrm{cm})$, number of spikelet's spike-1, number of kernels spike-1 and kernels weight spike-1 were determined. 1000kernel weight, number of spikes m-2 and grain and straw yields were determined in plot basis then transferred to ardab and ton fad-1, respectively.

Nitrogen use efficiency (NUE) was calculated as NUE $=$ Grain yield/ Nitrogen applied (Ali, 2010).

All data collected from each experiment under irrigation level were analyzed with analysis of variance (ANOVA) Procedures using the SAS Statistical Software Package (v.9.2, 2008).Then, combined analysis was carried out for irrigation levels to reveal the effect of this variable and the interaction involved. Means were compared by LSD at 5\% level of significant (Gomez and Gomez, 1984).

\section{Results and Discussion}

1-Vegetative traits:

Plant height $(\mathrm{cm})$ : Data presented in Table 2 show that irrigation levels, nitrogen fertilizer splitting, cultivars and their interaction had a significant influence $(p \leq 0.05)$ on wheat plant height in the two growing seasons. Thus, plant height was de- 
creased linearly by reducing amount of water applied to wheat plants and the tallest plants were registered from I1 treatment $(89.47$ and $87.42 \mathrm{~cm})$, while the shortest plants were obtained from I3 treatment (75.21 and $73.39 \mathrm{~cm}$ ) in the first and second seasons, respectively. This can be explained by the role of water in the cell division and elongation as well as the other physiological process such as photosynthesis, respiration and translocation. Depressed water potential suppresses cell division, organ growth, net photosynthesis, protein synthesis, and alters hormonal balances of major plant tissues (Moharram and Habib, 2011). Moreover, the splitting nitrogen fertilizer to four times increase plant height as compared to the other splitting treatment (two times) and the amount of increments were reached about 5.8 and 5.3 $\%$ in the first and second seasons, respectively. The increase in plant height by increasing $\mathrm{N}$ application number might be attributed to saving $\mathrm{N}$ in proper time and maximizing the $\mathrm{N}$ utilization through minimizing losses of the applied N.Similar results were reported by El-Agrodi et al. (2011). Furthermore, Sids-1 cultivar surpassed Giza-168 one and produced the highest mean values in this respect $(86.47$ and $83.97 \mathrm{~cm})$ in the first and second seasons, respectively. The differences between cultivars are mainly due to the interaction between their genetic makeup during growth periods and to the environmental factors prevailing during their development. These results are in agreement with that obtained by Al-Tabbal (2011). With regard to second order interaction, data exhibited in this respect reveal that cultivated Sidis-1 cultivar subjected to I1 irrigation level and received nitrogen fertilizer at four equal doses gained the highest mean values of plant height $(97.20$ and $91.17 \mathrm{~cm}$ ) in the first and second seasons, respectively. 
Table 2. Effect of irrigation levels, Nitrogen splitting, cultivars and their interactions on plant height $(\mathrm{cm})$

\begin{tabular}{|c|c|c|c|c|c|c|c|}
\hline \multicolumn{2}{|c|}{ Seasons } & \multicolumn{3}{|c|}{$2012 / 2013$} & \multicolumn{3}{|c|}{$2013 / 2014$} \\
\hline $\begin{array}{c}\text { Irrigation } \\
\text { Levels (I) }\end{array}$ & $\begin{array}{l}\text { Cultivars(C) } \\
\text { Splitting(S) }\end{array}$ & $\begin{array}{c}\text { Giza- } \\
168\end{array}$ & $\begin{array}{c}\text { Sids- } \\
1\end{array}$ & Mean & $\begin{array}{c}\text { Giza- } \\
168\end{array}$ & $\begin{array}{c}\text { Sids- } \\
1\end{array}$ & Mean \\
\hline \multirow[t]{2}{*}{$\overline{\mathbf{I}_{1}}$} & $\mathbf{S}_{1}$ & 85.30 & 86.73 & 86.02 & 85.00 & 85.93 & 85.47 \\
\hline & $\mathbf{S}_{\mathbf{2}}$ & 88.63 & 97.20 & 92.92 & 87.57 & 91.17 & 89.37 \\
\hline \multicolumn{2}{|c|}{ Mean } & 86.97 & 91.97 & 89.47 & 86.28 & 88.55 & 87.42 \\
\hline \multirow[t]{2}{*}{$\mathbf{I}_{2}$} & $\mathbf{S}_{1}$ & 80.00 & 81.33 & 80.67 & 79.27 & 80.17 & 79.72 \\
\hline & $\mathbf{S}_{2}$ & 82.13 & 84.13 & 83.13 & 81.80 & 83.10 & 82.45 \\
\hline \multicolumn{2}{|c|}{ Mean } & 81.07 & 82.73 & 81.90 & 80.53 & 81.63 & 81.08 \\
\hline \multirow[t]{2}{*}{$\mathbf{I}_{3}$} & $S_{1}$ & 71.57 & 74.40 & 72.99 & 67.73 & 73.10 & 70.42 \\
\hline & $\mathbf{S}_{2}$ & 76.80 & 78.07 & 77.44 & 75.07 & 77.63 & 76.35 \\
\hline \multicolumn{2}{|c|}{ Mean } & 74.18 & 76.23 & 75.21 & 71.40 & 75.37 & 73.39 \\
\hline \multicolumn{2}{|c|}{ General mean } & 80.74 & 83.64 & ------ & 79.41 & 81.85 & ------ \\
\hline \multirow[t]{2}{*}{$\mathbf{C} \times \mathbf{S}$} & $\mathbf{S}_{1}$ & 78.96 & 80.82 & 79.89 & 77.33 & 79.73 & 78.53 \\
\hline & $\mathbf{S}_{2}$ & 82.52 & 86.47 & 84.49 & 81.48 & 83.97 & 82.72 \\
\hline \multicolumn{2}{|c|}{ F test and LSD } & \multicolumn{2}{|c|}{ F test } & LSD & F test & \multicolumn{2}{|c|}{ LSD } \\
\hline \multicolumn{2}{|c|}{$\mathbf{I}$} & \multicolumn{2}{|l|}{$*$} & 1.888 & $*$ & \multicolumn{2}{|c|}{0.561} \\
\hline \multicolumn{2}{|c|}{$\mathbf{S}$} & \multicolumn{2}{|l|}{$*$} & ----- & $*$ & \multicolumn{2}{|c|}{------ } \\
\hline \multicolumn{2}{|c|}{$\mathrm{C}$} & \multicolumn{2}{|l|}{$*$} & ---- & $*$ & \multicolumn{2}{|c|}{----- } \\
\hline \multicolumn{2}{|c|}{$\mathbf{I} \times \mathbf{S}$} & \multicolumn{2}{|l|}{$*$} & 2.838 & $*$ & \multicolumn{2}{|c|}{1.282} \\
\hline \multicolumn{2}{|c|}{$\mathbf{I} \times \mathbf{C}$} & \multicolumn{2}{|l|}{$*$} & 1.335 & $*$ & \multicolumn{2}{|c|}{0.549} \\
\hline \multicolumn{2}{|c|}{$\mathbf{S} \times \mathbf{C}$} & \multicolumn{2}{|l|}{ * } & 1.090 & * & \multicolumn{2}{|c|}{0.448} \\
\hline \multicolumn{2}{|c|}{$\mathbf{I} \times \mathbf{S} \times \mathbf{C}$} & \multicolumn{2}{|l|}{ * } & 1.888 & $*$ & & 777 \\
\hline
\end{tabular}

Where: $\mathrm{I}_{1}, \mathrm{I}_{2}$ and $\mathrm{I}_{3}$ means 100,75 and $50 \%$ of irrigation requirement, respectively

$\mathrm{S}_{1}$ and $\mathrm{S}_{2}$ means two and four nitrogen fertilizer splitting, respectively

* means significantly at 5\% level of significant

Spike length (cm): Exhibited data in Table 3 reveal that irrigation levels, nitrogen fertilizer splitting, cultivars and their interaction involved had a significant influence $(\mathrm{p} \leq$ 0.05 ) on wheat spike length in the two growing seasons. Therefore, decreasing amount of irrigation water applied to wheat plants from I1 to I2or I3 decreased spike length from 12.58 to 11.21 or $8.55 \mathrm{~cm}$ in the first season, being 12.30 to 11.11 or 8.09 $\mathrm{cm}$ in the second season in the same order. This is to be expected since the same trend was found with regard to plant height and consequently spike length. Moreover, the splitting nitro- gen fertilizer to four times increase spike length as compared to the splitting nitrogen to two equal doses and gained 11.33 and 10.97 spike length in the first and second seasons, respectively. The increase in spike length by increasing $\mathrm{N}$ application number might be attributed to saving $\mathrm{N}$ in proper time and maximizing the $\mathrm{N}$ utilization through minimizing losses of the applied N. The similar results were reported by El-Agrodi et al. (2011). Furthermore, Sids-1 cultivar surpassed Giza-168 one and produced the highest mean values of spike length $(11.04$ and $10.79 \mathrm{~cm})$ in the first and second seasons, respec- 
tively. The differences between cultivars are mainly due to the interaction between their genetic makeup during growth periods and to the environmental factors prevailing during their development. These results are in agreement with that obtained by AlTabbal (2011). Concerning second order interaction data presented here state that cultivated Sidis-1 cultivar subjected to I1 irrigation level and received nitrogen fertilizer at four equal doses gained the highest mean values of spike length $(13.50$ and $13.10 \mathrm{~cm})$ in the first and second seasons, respectively.

Table 3. Effect of irrigation levels, Nitrogen splitting, cultivars and their interactions on spike length $(\mathrm{cm})$

\begin{tabular}{|c|c|c|c|c|c|c|c|}
\hline \multicolumn{2}{|c|}{ Seasons } & \multicolumn{3}{|c|}{$2012 / 2013$} & \multicolumn{3}{|c|}{ 2013/2014 } \\
\hline $\begin{array}{l}\text { Irrigation } \\
\text { levels(I) }\end{array}$ & $\begin{array}{l}\text { Cultivars(C) } \\
\text { Splitting(S) }\end{array}$ & Giza-168 & Sids-1 & Mean & Giza-168 & Sids-1 & Mean \\
\hline \multirow[t]{2}{*}{$\mathbf{I}_{1}$} & $S_{1}$ & 11.87 & 12.23 & 12.05 & 11.60 & 12.10 & 11.85 \\
\hline & \begin{tabular}{|l}
$S_{2}$ \\
\end{tabular} & 12.70 & 13.50 & 13.10 & 12.40 & 13.10 & 12.75 \\
\hline \multicolumn{2}{|c|}{$\frac{\mid \mathrm{O}_{2}}{\mathrm{Mean}}$} & 12.28 & 12.87 & 12.58 & 12.00 & 12.60 & 12.30 \\
\hline \multirow[t]{2}{*}{$\mathbf{I}_{2}$} & $S_{1}$ & 10.93 & 11.10 & 11.02 & 10.70 & 11.07 & 10.89 \\
\hline & $\mathbf{S}_{2}$ & 11.30 & 11.50 & 11.40 & 11.17 & 11.50 & 11.34 \\
\hline \multicolumn{2}{|c|}{ Mean } & 11.12 & 11.30 & 11.21 & 10.93 & 11.28 & 11.11 \\
\hline \multirow[t]{2}{*}{$\mathbf{I}_{3}$} & $\mathbf{S}_{1}$ & 7.37 & 7.83 & 7.60 & 7.03 & 7.63 & 7.33 \\
\hline & $\mathbf{S}_{2}$ & 8.90 & 10.09 & 9.50 & 8.30 & 9.37 & 8.84 \\
\hline \multicolumn{2}{|c|}{ Mean } & 8.13 & 8.96 & 8.55 & 7.67 & 8.50 & 8.09 \\
\hline \multicolumn{2}{|c|}{ General mean } & 10.51 & 11.04 & ------ & 10.20 & 10.79 & ----- \\
\hline \multirow[t]{2}{*}{$\mathbf{C} \times \mathbf{S}$} & $\mathbf{S}_{1}$ & 10.06 & 10.39 & 10.22 & 9.78 & 10.27 & 10.02 \\
\hline & $\mathbf{S}_{2}$ & 10.97 & 11.70 & 11.33 & 10.62 & 11.32 & 10.97 \\
\hline \multicolumn{2}{|c|}{ F test and LSD } & \multicolumn{2}{|l|}{ F test } & LSD & F test & \multicolumn{2}{|c|}{ LSD } \\
\hline \multicolumn{2}{|c|}{ I } & \multicolumn{2}{|l|}{$*$} & 0.279 & $*$ & & 0.174 \\
\hline \multicolumn{2}{|c|}{$\mathbf{S}$} & \multicolumn{2}{|l|}{$*$} & ----- & * & & $\begin{array}{l}----- \\
---\end{array}$ \\
\hline \multicolumn{2}{|c|}{ C } & \multicolumn{2}{|l|}{$*$} & ---- & $*$ & & $\begin{array}{l}----- \\
---\end{array}$ \\
\hline \multicolumn{2}{|c|}{$\mathbf{I} \times \mathbf{S}$} & \multirow{2}{*}{\multicolumn{2}{|c|}{$\frac{*}{*}$}} & 0.305 & $*$ & & 0.200 \\
\hline \multicolumn{2}{|c|}{$\mathbf{I} \times \mathbf{C}$} & & & 0.121 & * & & 0.068 \\
\hline \multicolumn{2}{|c|}{$\mathbf{S} \times \mathbf{C}$} & \multicolumn{2}{|l|}{$\frac{*}{*}$} & 0.099 & $*$ & & 0.056 \\
\hline & & \multicolumn{2}{|l|}{ * } & 0.171 & * & & 0.096 \\
\hline
\end{tabular}

\section{2- Yield components traits:}

Number of spikes $\mathrm{m}^{-2}$ : Data illustrated in Table 4 focus that the studied irrigation levels had a significant effect $(\mathrm{p} \leq 0.05)$ on the number of spikes $\mathrm{m}^{-2}$ in both seasons. Thus, number of spikes $\mathrm{m}^{-2}$ was decreased significantly with decreasing amount of water applied to wheat plants. Decreasing irrigation water amount from $\mathrm{I}_{1}$ to $\mathrm{I}_{2}$ or $\mathrm{I}_{3}$ resulting in the decrease in number of spikes $\mathrm{m}^{-2}$ reached about 11.36 and $23.99 \%$, respec- tively in the first season, being, 10.52 and $24.21 \%$ in the second season in the same order. This may be due to the effect of water stress on the tillering numbers which were decreased in order to irrigation water decreased. Moisture stress is known to reduce tillering ability when it occurs at any stage. So, the overall effect of moisture stress depends on intensity and length of stress (Bukhat, 2005). Furthermore, the data also reveal that the splitting nitrogen fertilizer had a sig- 
nificant influence $(\mathrm{p} \leq 0.05)$ in this respect in both seasons. Splitting nitrogen fertilizer into four equal doses produced the highest mean values of spikes number $\mathrm{m}^{-2}$ (426.7 and 420.3) in the first and second seasons, respectively. The beneficial effect of $\mathrm{N}$ splitting may be related to reduction of $\mathrm{N}$ losses and enhancement tillering in wheat. Moreover, the presented data state that wheat cultivars varied significantly in this respect in the two growing seasons. Thus, Giza -168 cultivar surpassed Sids-1 cultivar and produced the highest mean values of spikes number $\mathrm{m}^{-2}$ (417.9 and 409.0) in the first and second seasons, respectively. The differences between cultivars are mainly due to the interaction between their genetic makeup during growth periods and to the environmental factors prevailing during their development. These results are in agreement with that obtained by Al-Tabbal (2011). Furthermore, the first order interaction between irrigation and splitting or cultivars had a significant effect on spikes number $\mathrm{m}^{-2}$ in both seasons. On the other hand, the first order interaction between splitting and cultivar as well as the second order interaction among irrigation, splitting and cultivars don't affect significantly number of spikes $\mathrm{m}^{-2}$ in the two growing seasons.

Table 4. Effect of irrigation levels, Nitrogen splitting, cultivars and their interactions on number of spikes $\mathrm{m}^{-2}$

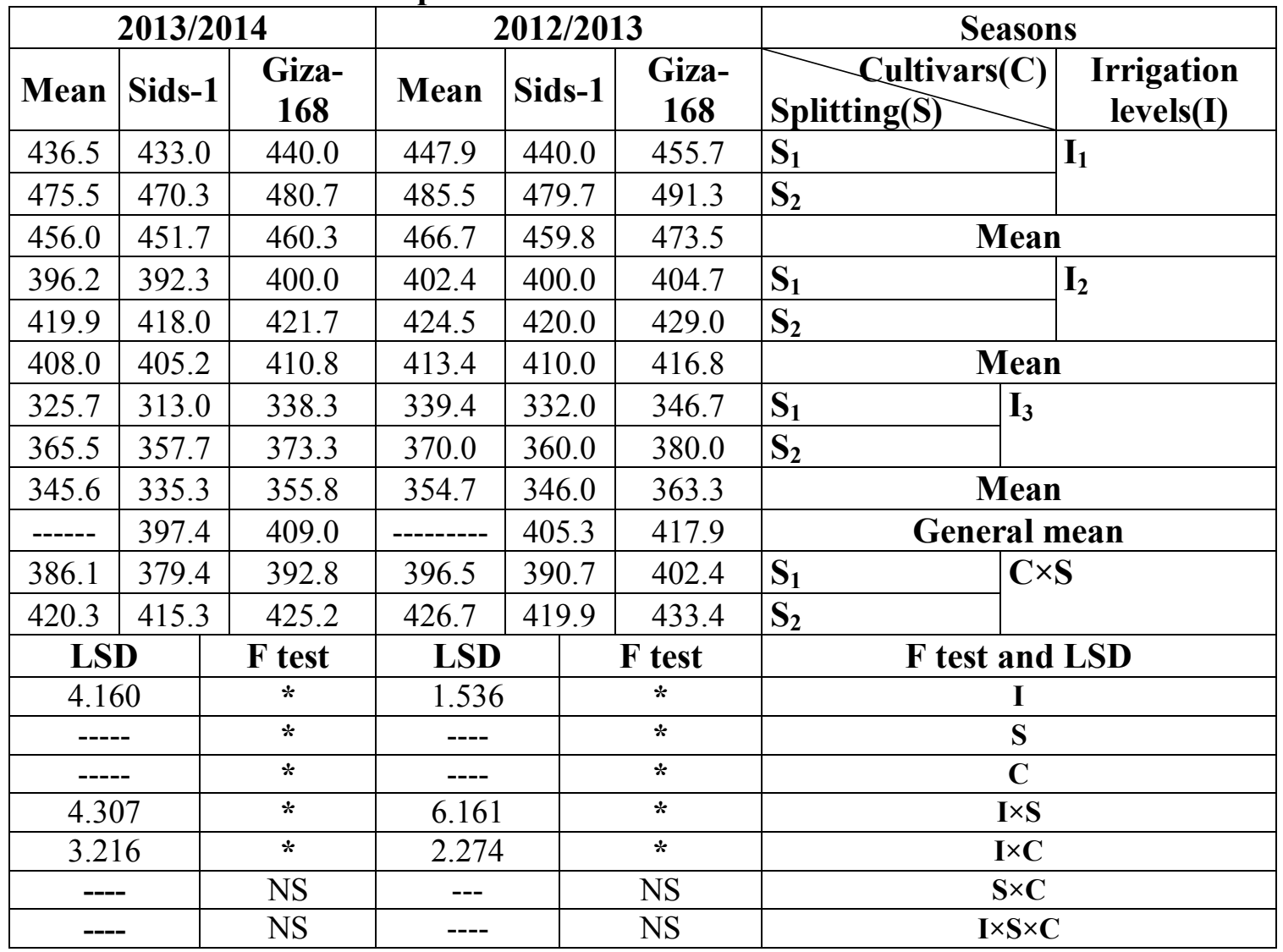


1000- Kernel weight (g): Exhibited data in Table 5 focus that irrigation levels, nitrogen fertilizer splitting, cultivars and their interactions involved here had a significant effect $(p \leq 0.05)$ on 1000 kernel weight in the two growing seasons except the effect of first order interaction between nitrogen fertilizer splitting and cultivars in the first season only. Significant differences in 1000 -grain weight were noted among various water stresstreatments. $I_{1}$ had significantly higher 1000 -grain weight than all other water stress treatments in both seasons. Similar effects of water stress on 1000-grain weight were also reported by Qadir et al. (1999), Dencic et al. (2000) and Akram (2011). Furthermore, the highest mean values of 1000- kernel weight (51.72 and $50.95 \mathrm{~g}$ ) in the first and second seasons, respectively, were obtained when nitrogen fertilizer was divided into four equal doses. The increase in 1000 kernel weight by increasing $\mathrm{N}$ application number might be attributed to saving $\mathrm{N}$ in proper time and maximizing the $\mathrm{N}$ utilization through minimizing losses of the applied $\mathrm{N}$ which led to high photosynthesis rates, increased the amount of carbohydrate accumulation in the kernels and consequently increased kernel weight. The obtained results are in a good line with those obtained by Hirzel et al.(2010), El-Agrodi et al. (2011) and Rahman et al. (2011). Concerning the studied cultivars effect, data show that Sids-1 cultivar surpassed Giza-168 one in this respect in both seasons. The differences between cultivars are mainly due to the interaction between their genetic makeup during growth periods and to the environmental factors prevailing during their development. These results are in agreement with that obtained by Al-Tabbal (2011) and Moharram and Habib (2011). Also, the data show that the highest mean values of 1000 kernel weight (59.17 and $58.18 \mathrm{~g})$ in the first and second seasons, respectively, were obtained from high irrigation level $\left(\mathrm{I}_{1}\right)$ with Sids-1 cultivar subjected to four splits of nitrogen fertilizer. 
Table 5. Effect of irrigation levels, Nitrogen splitting, cultivars and their interactions on 1000 kernel weight

\begin{tabular}{|c|c|c|c|c|c|c|c|}
\hline \multicolumn{3}{|c|}{$2013 / 2014$} & \multicolumn{3}{|c|}{$2012 / 2013$} & \multicolumn{2}{|c|}{ Seasons } \\
\hline Mean & $\begin{array}{c}\text { Sids- } \\
1\end{array}$ & $\begin{array}{c}\text { Giza- } \\
168\end{array}$ & Mean & $\begin{array}{c}\text { Sids- } \\
1\end{array}$ & $\begin{array}{c}\text { Giza- } \\
168\end{array}$ & $\begin{array}{l}\text { Cultivars(C) } \\
\text { Splitting(S) }\end{array}$ & $\begin{array}{c}\text { Irrigation } \\
\text { levels(I) }\end{array}$ \\
\hline 53.02 & 53.78 & 52.25 & 53.89 & 54.50 & 53.27 & $\mathbf{S}_{1}$ & \multirow{2}{*}{$\mathbf{I}_{\mathbf{1}}$} \\
\hline 56.66 & 58.18 & 55.13 & 57.84 & 59.17 & 56.50 & $\mathbf{S}_{2}$ & \\
\hline 54.84 & 55.98 & 53.69 & 55.86 & 56.83 & 54.88 & \multicolumn{2}{|c|}{ Mean } \\
\hline 47.90 & 48.37 & 47.43 & 48.41 & 49.07 & 47.75 & $S_{1}$ & \multirow[t]{2}{*}{$\mathbf{I}_{2}$} \\
\hline 50.61 & 51.38 & 49.83 & 51.13 & 51.77 & 50.48 & $\mathbf{S}_{2}$ & \\
\hline 49.26 & 49.88 & 48.63 & 49.77 & 50.42 & 49.12 & \multicolumn{2}{|c|}{ Mean } \\
\hline 42.23 & 43.57 & 40.88 & 43.07 & 43.92 & 42.22 & $\mathbf{S}_{1}$ & \multirow{2}{*}{$\mathbf{I}_{3}$} \\
\hline 45.60 & 46.03 & 45.17 & 46.19 & 46.75 & 45.63 & $\mathbf{S}_{2}$ & \\
\hline 43.92 & 44.80 & 43.03 & 44.63 & 45.33 & 43.93 & \multicolumn{2}{|c|}{ Mean } \\
\hline---- & 50.22 & 48.45 & $\begin{array}{ll}---- \\
\end{array}$ & 50.86 & 49.31 & \multicolumn{2}{|c|}{ General mean } \\
\hline 47.71 & 48.57 & 46.85 & 48.46 & 49.16 & 47.75 & $\mathbf{S}_{1}$ & \multirow{2}{*}{$\mathbf{C} \times \mathbf{S}$} \\
\hline 50.95 & 51.86 & 50.04 & 51.72 & 52.56 & 50.87 & $\mathbf{S}_{2}$ & \\
\hline \multicolumn{2}{|c|}{ LSD } & F test & LSD & & F test & \multicolumn{2}{|c|}{ F test and LSD } \\
\hline \multicolumn{2}{|c|}{0.129} & $*$ & 0.299 & & $*$ & \multicolumn{2}{|r|}{$\mathbf{I}$} \\
\hline \multicolumn{2}{|c|}{$\begin{array}{ll}--- \\
--1\end{array}$} & * & ---- & & $*$ & \multicolumn{2}{|r|}{$\mathbf{S}$} \\
\hline \multicolumn{2}{|c|}{$\begin{array}{ll}---- \\
--\end{array}$} & * & ---- & & $*$ & \multicolumn{2}{|c|}{$\mathbf{C}$} \\
\hline \multicolumn{2}{|c|}{0.207} & $*$ & 0.582 & & $*$ & \multicolumn{2}{|c|}{$\mathbf{I} \times \mathbf{S}$} \\
\hline \multicolumn{2}{|c|}{0.153} & $*$ & 0.252 & & $*$ & \multicolumn{2}{|c|}{$\mathbf{I} \times \mathbf{C}$} \\
\hline \multicolumn{2}{|c|}{0.125} & $*$ & ---- & & NS & \multirow{2}{*}{\multicolumn{2}{|c|}{$\frac{\mathbf{S} \times \mathbf{C}}{\mathbf{I} \times \mathbf{S} \times \mathbf{C}}$}} \\
\hline \multicolumn{2}{|c|}{0.217} & $*$ & 0.356 & & $*$ & & \\
\hline
\end{tabular}

Kernels weight spike $^{-1}$ : Data presented in Table 6 reveal that involved irrigation levels, nitrogen fertilizer splitting, cultivars and their interaction had a significant effect $(\mathrm{p} \leq$ 0.05 ) on kernels weight spike ${ }^{-1}$ trait in the two growing seasons. Thus, weight of kernels spike $^{-1}$ was decreased linearly by shortage in amount of water applied to wheat plants and the heaviest kernels spike ${ }^{-1}$ were registered from $I_{1}$ treatment (3.73 and $3.60 \mathrm{~g}$ ) while, the thin nest kernels spike ${ }^{-1}$ were obtained from $\mathrm{I}_{3}$ treatment $(2.68$ and $2.60 \mathrm{~g})$ in the first and second seasons, respectively. This is to be logic since the same trend was obtained with regard 1000 kernels weight and consequently weight of kernels spike ${ }^{-1}$. Similar effects of water stress on 1000grainweight were also reported by
Qadir et al. (1999), Dencic et al. (2000) and Akram (2011). Moreover, the splitting nitrogen fertilizer to four splits increased weight of kernels spike $^{-1}$ as compared to the other splitting treatment (two splits) and the amount of increments were reached about 11.49 and $14.13 \%$ in the first and second seasons, respectively. This is to be expected since the same split treatment produced the highest mean values with regard to 1000 kernels weight trait as mentioned before and consequently produced the highest mean values of kernel weight spike $^{-1}$. The similar results were reported by El-Agrodi etal.(2011). Furthermore, Sids-1 cultivar surpassed Giza-168 one and produced the highest mean values in this respect (3.14 and $3.05 \mathrm{~g}$ ) in the first and second seasons, respectively. This is logic 
since the same cultivar recorded the highest mean values with regard to 1000 kernels weight trait as mentioned before and consequently produced the highest mean values of kernels weight spike ${ }^{-1}$ trait. These results are in agreement with that obtained by Al-Tabbal (2011). Concerning the second order interaction, data illustrated in this respect focus that cultivated Sidis-1 cultivar subjected to $I_{1}$ irrigation level and received nitrogen fertilizer at four equal doses gained the highest mean values of kernels weight spike $^{-1}$ (3.96 and $3.91 \mathrm{~g}$ ) in the first and second seasons, respectively. This is to be expected since the same interaction was significant with regard to 1000 kernel weight.

Table 6. Effect of irrigation levels, Nitrogen splitting, cultivars and their interactions on kernels weight $\operatorname{spike}^{-1}(\mathrm{~g})$

\begin{tabular}{|c|c|c|c|c|c|c|c|}
\hline \multicolumn{3}{|c|}{$2013 / 2014$} & \multicolumn{3}{|c|}{$2012 / 2013$} & \multicolumn{2}{|c|}{ Seasons } \\
\hline Mean & Sids-1 & $\begin{array}{c}\text { Giza- } \\
168 \\
\end{array}$ & Mean & Sids-1 & $\begin{array}{c}\text { Giza- } \\
168\end{array}$ & $\begin{array}{l}\text { Cultivars(C) } \\
\text { Splitting(S) }\end{array}$ & $\begin{array}{c}\text { Irrigation } \\
\text { levels(I) }\end{array}$ \\
\hline 3.20 & 3.29 & 3.11 & 3.34 & 3.49 & 3.19 & $\mathbf{S}_{1}$ & $\mathbf{I}_{1}$ \\
\hline 3.76 & 3.91 & 3.61 & 3.84 & 3.96 & 3.73 & $\mathbf{S}_{2}$ & \\
\hline 3.48 & 3.60 & 3.36 & 3.60 & 3.73 & 3.46 & \multicolumn{2}{|c|}{ Mean } \\
\hline 2.84 & 2.88 & 2.80 & 2.88 & 2.92 & 2.83 & $\mathbf{S}_{1}$ & \multirow[t]{2}{*}{$\mathbf{I}_{2}$} \\
\hline 2.98 & 3.01 & 2.94 & 3.03 & 3.08 & 2.97 & $\mathbf{S}_{2}$ & \\
\hline 2.91 & 2.95 & 2.87 & 2.95 & 3.00 & 2.90 & \multicolumn{2}{|c|}{ Mean } \\
\hline 2.23 & 2.47 & 1.98 & 2.39 & 2.62 & 2.16 & $S_{1}$ & \multirow[t]{2}{*}{$\mathbf{I}_{3}$} \\
\hline 2.70 & 2.72 & 2.68 & 2.73 & 2.74 & 2.72 & $\mathbf{S}_{2}$ & \\
\hline 2.47 & 2.60 & 2.33 & 2.56 & 2.68 & 2.44 & \multicolumn{2}{|c|}{ Mean } \\
\hline ----- & 3.05 & 2.86 & ---- & 3.14 & 2.93 & \multicolumn{2}{|c|}{ General mean } \\
\hline 2.76 & 2.88 & 2.63 & 2.87 & 3.01 & 2.73 & $\mathbf{S}_{1}$ & \multirow[t]{2}{*}{$\mathbf{C} \times \mathbf{S}$} \\
\hline 3.15 & 3.21 & 3.08 & 3.20 & 3.26 & 3.14 & $\mathbf{S}_{2}$ & \\
\hline \multicolumn{2}{|c|}{ LSD } & F test & \multicolumn{2}{|c|}{ LSD } & F test & \multicolumn{2}{|c|}{ F test and LSD } \\
\hline \multicolumn{2}{|c|}{0.044} & $*$ & \multicolumn{2}{|c|}{0.057} & $*$ & \multicolumn{2}{|l|}{$\mathbf{I}$} \\
\hline \multicolumn{2}{|c|}{------ } & $*$ & \multicolumn{2}{|l|}{$-\cdots$} & $*$ & \multicolumn{2}{|l|}{$\mathbf{S}$} \\
\hline \multicolumn{2}{|c|}{------ } & $*$ & \multicolumn{2}{|l|}{$\begin{array}{ll}--- \\
-\cdots\end{array}$} & $*$ & \multicolumn{2}{|l|}{ C } \\
\hline \multicolumn{2}{|c|}{0.055} & * & \multicolumn{2}{|c|}{0.119} & $*$ & \multicolumn{2}{|l|}{$\mathbf{I} \times \mathbf{S}$} \\
\hline \multicolumn{2}{|c|}{0.025} & $*$ & \multicolumn{2}{|c|}{0.049} & $*$ & \multicolumn{2}{|l|}{$\mathbf{I} \times \mathbf{C}$} \\
\hline \multicolumn{2}{|c|}{0.020} & $*$ & \multicolumn{2}{|c|}{0.040} & $*$ & \multicolumn{2}{|c|}{$\mathbf{S} \times \mathbf{C}$} \\
\hline \multicolumn{2}{|c|}{0.035} & $*$ & \multicolumn{2}{|c|}{0.069} & $*$ & \multicolumn{2}{|c|}{$\mathbf{I} \times \mathbf{S} \times \mathbf{C}$} \\
\hline
\end{tabular}

Biological yield (ton fed..$^{-1}$ ): Data illustrated in Table 7 focus that the studied irrigation levels had a significant effect $(\mathrm{p} \leq 0.05)$ on the biological yield in both seasons. Thus, biological yield was decreased significantly with decreasing amount of water applied to wheat plants. Decreasing irrigation water amount from
$\mathrm{I}_{1}$ to $\mathrm{I}_{2}$ or $\mathrm{I}_{3}$ resulting in the decrease in biological yield reached about 13.44 and $42.56 \%$, respectively in the first season, being, 13.41 and $45.67 \%$ in the second season in the same order. This is to be expected since the same trend was obtained with regard to plant height, number of spikes $\mathrm{m}^{-2}$ and weight of kernels 
spike $^{-1}$ as mentioned previous. These findings were in a good line with those obtained by Qadir et al. (1999), Dencic et al. (2000) and Akram (2011). Furthermore, the data also, reveal that splitting nitrogen fertilizer had a significant influence $(\mathrm{p} \leq 0.05)$ on the biological yield in both seasons. Splitting nitrogen fertilizer into four equal doses produced the highest mean values of biological yield (9.14 and $8.77 \mathrm{t} \mathrm{fed}^{-1}$ ) in the first and second seasons, respectively. This is logic since the same trend was obtained with regard to plant height, number of spikes $\mathrm{m}^{-2}$ and weight of kernels spike ${ }^{-1}$ as mentioned previous. Moreover, the presented data state that wheat cultivars varied significantly in this respect in the two growing seasons. Thus, Sids-1 cultivar surpassed Giza -168 one and produced the highest mean values of biological yield (8.90 and $\left.8.54 \mathrm{t} \mathrm{fed}^{-1}\right)$ in the first and second seasons, respectively. The differences between culti- vars are mainly due to the interaction between their genetic makeup during growth periods and to the environmental factors prevailing during their development. These results are in agreement with that obtained by AlTabbal (2011). Furthermore, the first order interaction between irrigation and splitting or cultivars had a significant effect on biological yield in both seasons. On the other hand, the first order interaction between splitting and cultivar as well as the second order interaction among irrigation, splitting and cultivars don't affect significantly biological yield in the first season only, while the effects of previous interactions are significant in the second season. Thus, the highest mean value of biological yield $\left(10.80 \mathrm{t} \mathrm{fed}^{-1}\right)$ in the second season was obtained fromSids-1 cultivar subjected to $I_{1}$ irrigation level and received nitrogen fertilizer at four splits. 
Table 7. Effect of irrigation levels, Nitrogen splitting, cultivars and their interactions on biological yield (ton fed $^{-1}$ )

\begin{tabular}{|c|c|c|c|c|c|c|c|}
\hline \multicolumn{3}{|c|}{$2013 / 2014$} & \multicolumn{3}{|c|}{ 2012/2013 } & \multicolumn{2}{|c|}{ Seasons } \\
\hline Mean & Sids-1 & Giza-168 & Mean & Sids-1 & Giza-168 & $\begin{array}{l}\text { Cultivars }(C) \\
\text { Splitting(S) }\end{array}$ & $\begin{array}{l}\text { Irrigation } \\
\text { levels(I) }\end{array}$ \\
\hline 9.98 & 10.00 & 9.96 & 10.13 & 10.27 & 10.00 & $\mathbf{S}_{1}$ & $I_{1}$ \\
\hline 10.60 & 10.80 & 10.40 & 10.98 & 11.24 & 10.72 & $\mathbf{S}_{2}$ & \\
\hline 10.29 & 10.40 & 10.18 & 10.56 & 10.75 & 10.36 & \multicolumn{2}{|c|}{ Mean } \\
\hline 8.42 & 8.80 & 8.03 & 8.77 & 8.96 & 8.57 & $\overline{S_{1}}$ & \multirow[t]{2}{*}{$\mathbf{I}_{2}$} \\
\hline 9.40 & 9.60 & 9.20 & 9.51 & 9.68 & 9.33 & $\mathbf{S}_{2}$ & \\
\hline 8.91 & 9.20 & 8.62 & 9.14 & 9.32 & 8.95 & \multicolumn{2}{|c|}{ Mean } \\
\hline 4.88 & 5.40 & 4.35 & 5.43 & 5.84 & 5.02 & $\overline{S_{1}}$ & \multirow[t]{2}{*}{$\mathbf{I}_{3}$} \\
\hline 6.30 & 6.64 & 5.95 & 6.94 & 7.42 & 6.45 & $\mathbf{S}_{2}$ & \\
\hline 5.59 & 6.02 & 5.15 & 6.19 & 6.63 & 5.74 & \multicolumn{2}{|c|}{ Mean } \\
\hline---- & 8.54 & 7.98 & ----- & 8.90 & 8.35 & \multicolumn{2}{|c|}{ General mean } \\
\hline 7.76 & 8.07 & 7.45 & 8.11 & 8.36 & 7.86 & $\mathrm{C} \times$ & \multirow[t]{2}{*}{$\mathbf{C} \times \mathbf{S}$} \\
\hline 8.77 & 9.01 & 8.52 & 9.14 & 9.45 & 8.84 & $\mathbf{S}_{2}$ & \\
\hline \multicolumn{2}{|c|}{ LSD } & F test & \multicolumn{2}{|c|}{ LSD } & F test & \multicolumn{2}{|c|}{ F test and LSD } \\
\hline \multicolumn{2}{|c|}{0.150} & $*$ & \multicolumn{2}{|c|}{0.150} & $*$ & \multicolumn{2}{|l|}{ I } \\
\hline \multicolumn{2}{|c|}{---- } & $*$ & \multicolumn{2}{|c|}{---- } & $*$ & \multicolumn{2}{|l|}{$\mathbf{S}$} \\
\hline \multicolumn{2}{|c|}{---- } & * & \multicolumn{2}{|l|}{---- } & * & \multicolumn{2}{|l|}{ C } \\
\hline \multicolumn{2}{|c|}{0.275} & $*$ & \multicolumn{2}{|c|}{0.085} & $*$ & \multicolumn{2}{|l|}{$\mathbf{I} \times \mathbf{S}$} \\
\hline \multicolumn{2}{|c|}{0.068} & $*$ & \multicolumn{2}{|c|}{0.093} & $*$ & \multicolumn{2}{|l|}{$\mathbf{I} \times \mathbf{C}$} \\
\hline \multicolumn{2}{|c|}{0.056} & * & \multicolumn{2}{|l|}{----} & NS & \multicolumn{2}{|l|}{$\mathbf{S} \times \mathbf{C}$} \\
\hline \multicolumn{2}{|c|}{0.097} & * & \multicolumn{2}{|l|}{---- } & NS & \multicolumn{2}{|c|}{$\mathbf{I} \times \mathbf{S} \times \mathbf{C}$} \\
\hline
\end{tabular}

Grain yield (ardab fed. ${ }^{-1}$ ): Data exhibited in Table 8 focus that the studied irrigation levels had a significant effect $(\mathrm{p} \leq 0.05)$ on the grain yield in both seasons. Thus, grain yield was decreased significantly with decreasing amount of water applied to wheat plants. Decreasing irrigation water amount from $I_{1}$ to $I_{2}$ or $I_{3}$ resulting in the decrease in grain yield reached about 33.15 and $47.85 \%$, respectively in the first season, being, 32.17 and $48.43 \%$ in the second season in the same order. This is to be expected since the same trend was obtained with regard to 1000 kernels weight, weight of kernels spike ${ }^{-1}$ and biological yield as mentioned previous. These findings were in a good line with those obtained by Qadir et al. (1999), Dencic et al. (2000) and Ak- ram (2011). Furthermore, the data also, reveal that splitting nitrogen fertilizer had a significant influence $(p \leq 0.05)$ on the grain yield in both seasons. Splitting nitrogen fertilizer into four equal doses produced the highest mean values of grain yield (18.95 and 18.45 ardab fed $^{-1}$ ) in the first and second seasons, respectively. This is logic since the same trend was obtained with regard to 1000 kernels weight, weight of kernels spike ${ }^{-1}$ and biological yield as mentioned previous. Moreover, the presented data state that wheat cultivars varied significantly in this respect in the two growing seasons. Thus, Sids-1 cultivar surpassed Giza -168 one and produced the highest mean values of grain yield (18.19 and $17.64 \mathrm{ardab} \mathrm{fed}^{-1}$ ) in the first and second seasons, respectively. This is 
logic since the same trend was observed with regard to weight of kernels spike ${ }^{-1}$. The differences between cultivars are mainly due to the interaction between their genetic makeup during growth periods and to the environmental factors prevailing during their development. These results are in agreement with that obtained by Al-Tabbal (2011). Furthermore, the all first order interactions in this respect had a significant effect on grain yield in both seasons. Also, the second order interaction among irrigation, splitting and cultivars had a significant effect on grain yield in the two growing season. Thus, the highest mean value of grain yield (28.13 and 28.02 ardab $\left.^{-1} \mathrm{fe}^{-1}\right)$ in the first and second seasons, respectively, were obtained from Sids-1 cultivar subjected to $\mathrm{I}_{1}$ irrigation level and received nitrogen fertilizer at four splits.

Table 8. Effect of irrigation levels, Nitrogen splitting, cultivars and their interactions on grain yield ( ardab fed $^{-1}$ )

\begin{tabular}{|c|c|c|c|c|c|c|c|}
\hline \multicolumn{3}{|c|}{$2013 / 2014$} & \multicolumn{3}{|c|}{ 2012/2013 } & \multicolumn{2}{|c|}{ Seasons } \\
\hline Mean & Sids-1 & $\begin{array}{c}\text { Giza- } \\
168\end{array}$ & Mean & Sids-1 & $\begin{array}{c}\text { Giza- } \\
168 \\
\end{array}$ & $\begin{array}{c}\text { Cultivars(C) } \\
\text { Splitting(S) }\end{array}$ & $\begin{array}{c}\text { Irrigation } \\
\text { levels(I) }\end{array}$ \\
\hline 19.58 & 21.03 & 18.12 & 20.98 & 22.32 & 19.63 & $\mathbf{S}_{1}$ & $\mathbf{I}_{1}$ \\
\hline 25.91 & 28.02 & 23.80 & 26.61 & 28.13 & 25.09 & $\mathbf{S}_{\mathbf{2}}$ & \\
\hline 22.75 & 24.53 & 20.96 & 23.80 & 25.23 & 22.36 & \multicolumn{2}{|c|}{ Mean } \\
\hline 14.52 & 15.07 & 13.96 & 14.92 & 15.33 & 14.51 & $\mathbf{S}_{1}$ & \multirow[t]{2}{*}{$\mathbf{I}_{2}$} \\
\hline 16.36 & 16.80 & 15.91 & 16.89 & 17.30 & 16.47 & $\mathbf{S}_{2}$ & \\
\hline 15.43 & 15.93 & 14.93 & 15.91 & 16.32 & 15.49 & \multicolumn{2}{|c|}{ Mean } \\
\hline 10.38 & 11.52 & 9.24 & 11.48 & 12.26 & 10.69 & $\mathbf{S}_{1}$ & \multirow[t]{2}{*}{$\mathbf{I}_{3}$} \\
\hline 13.08 & 13.39 & 12.76 & 13.35 & 13.82 & 12.87 & $\mathbf{S}_{2}$ & \\
\hline 11.73 & 12.45 & 11.00 & 12.41 & 13.04 & 11.78 & \multicolumn{2}{|c|}{ Mean } \\
\hline ----- & 17.64 & 15.63 & ----- & 18.19 & 16.54 & \multicolumn{2}{|c|}{ General mean } \\
\hline 14.82 & 15.87 & 13.77 & 15.79 & 16.64 & 14.94 & $\mathbf{S}_{1}$ & \multirow[t]{2}{*}{$\mathbf{C} \times \mathbf{S}$} \\
\hline 18.45 & 19.40 & 17.49 & 18.95 & 19.75 & 18.14 & $\mathbf{S}_{2}$ & \\
\hline \multicolumn{2}{|c|}{ LSD } & F test & \multicolumn{2}{|l|}{ LSD } & F test & \multicolumn{2}{|c|}{ F test and LSD } \\
\hline \multicolumn{2}{|c|}{0.610} & $*$ & \multirow{2}{*}{\multicolumn{2}{|c|}{$\frac{0.232}{-----}$}} & $*$ & \multicolumn{2}{|c|}{ I } \\
\hline \multicolumn{2}{|c|}{----- } & * & & & * & \multicolumn{2}{|c|}{$\mathbf{S}$} \\
\hline \multicolumn{2}{|c|}{----} & $*$ & \multicolumn{2}{|l|}{-} & $*$ & \multirow{2}{*}{\multicolumn{2}{|c|}{$\begin{array}{c}\mathbf{C} \\
\mathbf{I} \times \mathbf{S}\end{array}$}} \\
\hline \multirow{2}{*}{\multicolumn{2}{|c|}{$\frac{0.727}{0.261}$}} & $*$ & \multicolumn{2}{|c|}{0.350} & $*$ & & \\
\hline & & $*$ & \multicolumn{2}{|c|}{0.152} & * & \multicolumn{2}{|c|}{$\mathbf{I} \times \mathbf{C}$} \\
\hline \multicolumn{2}{|c|}{0.213} & $*$ & \multirow{2}{*}{\multicolumn{2}{|c|}{0.124}} & * & \multicolumn{2}{|c|}{$\mathbf{S} \times \mathbf{C}$} \\
\hline \multicolumn{2}{|c|}{0.370} & * & & & * & \multicolumn{2}{|c|}{$\mathbf{I} \times \mathbf{S} \times \mathbf{C}$} \\
\hline
\end{tabular}

Straw yield (t fed. $\left.{ }^{-1}\right)$ : Data exhibited in Table 9 focus that the studied irrigation levels had a significant effect $(\mathrm{p} \leq 0.05)$ on the straw yield in both seasons. Thus, straw yield was decreased significantly with decreas- ing amount of water applied to wheat plants. Decreasing irrigation water amount from $I_{1}$ to $I_{2}$ or $I_{3}$ resulting in the decrease in straw yield reached about 3.43 and $38.05 \%$, respectively in the first season, being, 4.07 and 
$44.33 \%$ in the second season in the same order. This is to be expected since the same trend was obtained with regard to biological yield as mentioned previous. These findings were in a good line with those obtained by Qadir et al. (1999), Dencic et al. (2000) and Akram (2011). Furthermore, the data also, reveal that splitting nitrogen fertilizer had a significant influence $(p \leq 0.05)$ on the straw yield in both seasons. Splitting nitrogen fertilizer into four equal doses produced the highest mean values of straw yield (6.30 and $6.00 \mathrm{t}$ $\mathrm{fed}^{-1)}$ in the first and second seasons, respectively. This is logic since the same trend was obtained with regard to biological yield as mentioned previous. Moreover, the presented data state that wheat cultivars varied significantly in this respect in the two growing seasons. Thus, Sids-1 cultivar surpassed Giza -168 one and produced the highest mean values of straw yield (6.17 and 5.89t fed $\mathrm{f}^{-1)}$ in the first and second seasons, respectively. This is logic since the same trend was observed with regard to biological yield as mentioned before. The differences between cultivars are mainly due to the interaction between their genetic makeup during growth periods and to the environmental factors prevailing during their development. These results are in agreement with that obtained by AlTabbal (2011). Furthermore, the all first order interactions in this respect had a significant effect on straw yield in both seasons. Also, the second order interaction among irrigation, splitting and cultivars had a significant effect on straw yield in the two growing season. Thus, the highest mean value of straw yield (7.06 and $7.24 \mathrm{t} \mathrm{fed}^{-1)}$ in the first and second seasons, respectively was obtained from Giza-168 cultivar subjected to $I_{1}$ irrigation level and received nitrogen fertilizer at two splits. 
Table 9. Effect of irrigation levels, Nitrogen splitting, cultivars and their interactions on straw yield (ton fed $^{-1}$ )

\begin{tabular}{|c|c|c|c|c|c|c|c|}
\hline \multicolumn{3}{|c|}{$2013 / 2014$} & \multicolumn{3}{|c|}{$2012 / 2013$} & \multicolumn{2}{|c|}{ Seasons } \\
\hline Mean & Sids-1 & $\begin{array}{c}\text { Giza- } \\
168\end{array}$ & Mean & Sids-1 & $\begin{array}{c}\text { Giza- } \\
168\end{array}$ & $\begin{array}{c}\text { Cultivars(C) } \\
\text { Splitting(S) }\end{array}$ & $\begin{array}{c}\text { Irrigation } \\
\text { levels(I) }\end{array}$ \\
\hline 7.04 & 6.85 & 7.24 & 6.98 & 6.92 & 7.06 & $\mathbf{S}_{1}$ & \multirow[t]{2}{*}{$\mathbf{I}_{1}$} \\
\hline 6.71 & 6.60 & 6.83 & 6.99 & 7.02 & 6.96 & $\mathbf{S}_{2}$ & \\
\hline 6.88 & 6.72 & 7.04 & 6.99 & 6.97 & 7.01 & \multicolumn{2}{|l|}{ Mean } \\
\hline 6.24 & 6.54 & 5.94 & 6.53 & 6.66 & 6.39 & $\mathbf{S}_{1}$ & \multirow[t]{2}{*}{$\mathbf{I}_{2}$} \\
\hline 6.95 & 7.08 & 6.81 & 6.98 & 7.09 & 6.86 & $\mathbf{S}_{2}$ & \\
\hline 6.60 & 6.81 & 6.38 & 6.75 & 6.87 & 6.63 & \multicolumn{2}{|l|}{ Mean } \\
\hline 3.32 & 3.67 & 2.96 & 3.71 & 4.00 & 3.42 & $S_{1}$ & \multirow[t]{2}{*}{$\mathbf{I}_{3}$} \\
\hline 4.34 & 4.63 & 4.04 & 4.94 & 5.35 & 4.52 & $\mathbf{S}_{\mathbf{2}}$ & \\
\hline 3.83 & 4.15 & 3.50 & 4.33 & 4.67 & 3.97 & \multicolumn{2}{|l|}{ Mean } \\
\hline $\begin{array}{c}-- \\
--\end{array}$ & 5.89 & 5.64 & $\begin{array}{ll}--- \\
-\end{array}$ & 6.17 & 5.87 & \multicolumn{2}{|l|}{ General mean } \\
\hline 5.54 & 5.69 & 5.38 & 5.74 & 5.86 & 5.62 & $\mathbf{S}_{1}$ & \multirow[t]{2}{*}{$\mathbf{C} \times \mathbf{S}$} \\
\hline 6.00 & 6.10 & 5.90 & 6.30 & 6.49 & 6.12 & $\mathbf{S}_{\mathbf{2}}$ & \\
\hline \multicolumn{2}{|c|}{ LSD } & F test & \multirow{2}{*}{\multicolumn{2}{|c|}{$\begin{array}{c}\text { LSD } \\
0.078\end{array}$}} & F test & \multicolumn{2}{|l|}{$F$ test and LSD } \\
\hline \multicolumn{2}{|c|}{0.303} & $*$ & & & $*$ & \multicolumn{2}{|l|}{ I } \\
\hline \multicolumn{2}{|c|}{---- } & $*$ & \multicolumn{2}{|c|}{--- } & $*$ & \multicolumn{2}{|l|}{$\mathbf{S}$} \\
\hline \multicolumn{2}{|c|}{---- } & $*$ & \multicolumn{2}{|l|}{---- } & $*$ & \multicolumn{2}{|l|}{ C } \\
\hline \multicolumn{2}{|c|}{0.330} & $*$ & \multicolumn{2}{|c|}{0.069} & $*$ & \multicolumn{2}{|l|}{$\mathbf{I} \times \mathbf{S}$} \\
\hline \multicolumn{2}{|c|}{0.190} & $*$ & \multicolumn{2}{|c|}{0.061} & $*$ & \multicolumn{2}{|l|}{$\mathbf{I} \times \mathbf{C}$} \\
\hline \multicolumn{2}{|c|}{0.155} & $*$ & \multicolumn{2}{|c|}{0.050} & $*$ & \multicolumn{2}{|l|}{$S \times C$} \\
\hline \multicolumn{2}{|c|}{0.268} & $*$ & \multicolumn{2}{|c|}{0.086} & $*$ & \multicolumn{2}{|l|}{$\mathbf{I} \times \mathbf{S} \times \mathbf{C}$} \\
\hline
\end{tabular}

Nitrogen use efficiency (NUE): Data exhibited in Table 10 focus that the irrigation levels studied had a significant effect $(\mathrm{p} \leq 0.05)$ on the NUE in both seasons. Thus, NUE was decreased significantly with decreasing amount of water applied to wheat plants. Decreasing irrigation water amount from $I_{1}$ to $I_{2}$ or $\mathrm{I}_{3}$ resulting in the decrease in NUE reached about 33.16 and $47.85 \%$, respectively in the first season, being, 32.12 and $48.42 \%$ in the second season in the same order. This is to be expected since the same trend was obtained with regard to grain yield as mentioned previous. Furthermore, the data also, reveal that splitting nitrogen fertilizer had a significant influence $(\mathrm{p} \leq 0.05)$ on the NUE yield in the two growing seasons. Splitting nitrogen fertilizer into four equal doses produced the highest mean values of NUE (37.90 and $36.89 \mathrm{~kg}$ grain $/ \mathrm{kg} \mathrm{N}$ applied) in the first and second seasons, respectively. This is logic since the same trend was obtained with regard to grain yield as mentioned previous. Similar obtained were found by Rahman et al., (2002) and Rahman et al. (2011). Moreover, the presented data state that wheat cultivars varied significantly in this respect in the two growing seasons. Thus, Sids- 1 cultivar surpassed Giza -168 one and produced the highest mean values of NUE (36.39 and $35.27 \mathrm{~kg}$ grain $/ \mathrm{kg} \mathrm{N}$ applied) in the first and second seasons, respectively. This is logic since the same trend was observed with regard to grain yield. The differences 
between cultivars are mainly due to the interaction between their genetic makeup during growth periods and to the environmental factors prevailing during their development. These results are in agreement with that obtained by Rahman et al. (2002). Furthermore, the all first order interactions in this respect had a significant effect on NUE in both seasons. Also, the second order interaction among irrigation, splitting and cultivars had a significant effect on NUE in the two growing season. Thus, the highest mean value of NUE (56.26 and $56.03 \mathrm{~kg}$ grain $/ \mathrm{kg} \mathrm{N}$ applied) in the first and second seasons, respectively, was obtained from Sids- 1 cultivar subjected to $I_{1}$ irrigation level and received nitrogen fertilizer at four splits.

Table 10. Effect of irrigation levels, Nitrogen splitting, cultivars and their interactions on nitrogen use efficiency (NUE) $\mathrm{kg} / \mathrm{kg} \mathrm{N}$.

\begin{tabular}{|c|c|c|c|c|c|c|c|}
\hline \multicolumn{3}{|c|}{$2013 / 2014$} & \multicolumn{3}{|c|}{$2012 / 2013$} & \multicolumn{2}{|c|}{ Seasons } \\
\hline Mean & Sids-1 & $\begin{array}{c}\text { Giza- } \\
168\end{array}$ & Mean & Sids-1 & $\begin{array}{c}\text { Giza- } \\
168\end{array}$ & $\begin{array}{c}\text { Cultivars(C) } \\
\text { Splitting(S) }\end{array}$ & $\begin{array}{c}\text { Irrigation } \\
\text { levels(I) }\end{array}$ \\
\hline 39.16 & 42.06 & 36.25 & 41.95 & 44.65 & 39.25 & $S_{1}$ & \multirow[t]{2}{*}{$\mathbf{I}_{1}$} \\
\hline 51.81 & 56.03 & 47.59 & 53.23 & 56.26 & 50.19 & $\mathbf{S}_{2}$ & \\
\hline 45.48 & 49.05 & 41.92 & 47.59 & 50.46 & 44.72 & \multicolumn{2}{|l|}{ Mean } \\
\hline 29.02 & 30.13 & 27.91 & 29.84 & 30.67 & 29.01 & $\mathbf{S}_{1}$ & \multirow[t]{2}{*}{$\mathbf{I}_{2}$} \\
\hline 32.71 & 33.60 & 31.82 & 33.77 & 34.60 & 32.94 & $\mathbf{S}_{2}$ & \\
\hline 30.87 & 31.87 & 29.87 & 31.81 & 32.64 & 30.98 & \multicolumn{2}{|l|}{ Mean } \\
\hline 20.77 & 23.04 & 18.49 & 22.96 & 24.54 & 21.37 & $\mathbf{S}_{1}$ & \multirow[t]{2}{*}{$\mathbf{I}_{3}$} \\
\hline 26.15 & 26.77 & 25.53 & 26.69 & 27.64 & 25.74 & $\mathbf{S}_{2}$ & \\
\hline 23.46 & 24.91 & 22.01 & 24.82 & 26.09 & 23.56 & \multicolumn{2}{|l|}{ Mean } \\
\hline $\begin{array}{l}---- \\
--\end{array}$ & 35.27 & 31.27 & ----- & 36.39 & 33.08 & \multicolumn{2}{|l|}{ General mean } \\
\hline 29.65 & 31.74 & 27.55 & 31.58 & 33.29 & 29.88 & $\mathbf{S}_{1}$ & \multirow[t]{2}{*}{$\mathbf{C} \times \mathbf{S}$} \\
\hline 36.89 & 38.80 & 34.98 & 37.90 & 39.50 & 36.29 & $\mathbf{S}_{2}$ & \\
\hline \multicolumn{2}{|c|}{ LSD } & F test & \multicolumn{2}{|c|}{ LSD } & F test & \multicolumn{2}{|l|}{ F test and LSD } \\
\hline \multicolumn{2}{|c|}{0.247} & * & \multicolumn{2}{|c|}{0.119} & * & \multicolumn{2}{|l|}{ I } \\
\hline \multicolumn{2}{|c|}{---- } & $*$ & \multicolumn{2}{|l|}{--- } & $*$ & \multicolumn{2}{|l|}{$\mathbf{S}$} \\
\hline \multicolumn{2}{|c|}{----} & $*$ & \multicolumn{2}{|l|}{----} & $*$ & \multicolumn{2}{|l|}{ C } \\
\hline \multicolumn{2}{|c|}{0.252} & $*$ & \multicolumn{2}{|c|}{0.118} & $*$ & \multicolumn{2}{|l|}{$\mathbf{I} \times \mathbf{S}$} \\
\hline \multicolumn{2}{|c|}{0.282} & $*$ & \multicolumn{2}{|c|}{0.154} & $*$ & \multicolumn{2}{|l|}{$\mathbf{I} \times \mathbf{C}$} \\
\hline \multicolumn{2}{|c|}{0.194} & * & \multicolumn{2}{|c|}{0.132} & * & \multicolumn{2}{|l|}{$\mathrm{S} \times \mathrm{C}$} \\
\hline \multicolumn{2}{|c|}{0.279} & $*$ & \multicolumn{2}{|c|}{0.219} & $*$ & $\mathbf{I} \times \mathbf{S} \times \mathbf{C}$ & \\
\hline
\end{tabular}

\section{References}

Akram, M. (2011). Growth and yield components of wheat under water stress of different growth stages. Bangladesh J. Agri. Res. 36(3): 455-468.

Ali, E.A. (2010). Grain yield and nitrogen use efficiency of pearl millet as affected by plant density, nitro- gen rate and splitting in sandy soil. American-Eurasian J. Agric. \& Environ. Sci., 7(3): 327-335.

Al-Tabbal, J.A. (2011). Effect of water stress on the yield and yield component of durum wheat cultivars (Triticum turgidum L. Var. durum). International J., (3):98-114. 
Awad A.M.; H. El-Zaher; M.A. Moustafa; M.A. Sayed and A.M. Osman (2000). Wheat production on sandy soils using different fertilization methods and irrigation regimes. J. Agric. Res. 45 (1): 3561.

Bukhat, N. M. (2005). Studies in yield and yield associated traits of wheat (Triticum aestivum L.) genotypes under drought conditions. M.Sc Thesis Department of Agronomy. Sindh Agriculture University, Tandojam, Pakistan.

Debaeke, P.; T. Aussenac; J.L. Fabre; A. Hilaire; B. Pujol and L. Thuries (1996). Grain nitrogen content of winter bread wheat (Triticum aestivum L.) as related to crop management and to the previous crop. Eur. J. Agron. 5:273-286.

Dencic, S.; R. Kastori; B. Kobiljski and B. Duggan (2000). Evaluation of grain yield and its components in wheat cultivars and land races under near optimal and drought conditions. Euphytica 1: 43-52.

El-Agrodi, M. W.; A. M. EL-Ghamry and H. H. Ibrahim (2011). Effect of nitrogen fertilizer rates, timing and splitting application on wheat plant grown on reclaimed soils. J. Soil Sci. and Agric. Eng., Mansoura Univ., Vol. 2 (9): 915 - 925.

Erekul, O.; K.G. Peter and T. Gurbuzt (2012). Effect of supplemental irrigation on yield and bread making quality of wheat (Triticum aestivum L.) varieties under the Mediterranean climatical conditions. Turkish Journal of Field Crops, 2012, 17(1):78-86.

FAO

http://faostat.fao.org/site/567/Des ktopDefault.aspx?.

Feil, B. (1997). The inverse yieldprotein relationship in cereals: possibilities and limitations for genetically improving the grain protein yield. Trends Agron. 1:103-119.

Gomez, K.A. and A.A. Gomez (1984). Statistical Procedures For Agriculture Research. A Wiley - Inter Science Publication, John wiley sons, lnc. New York, USA.

Hirzel, J.; I. Matus and R.Madariaga (2010). Effect of split nitrogen applications on durum wheat cultivars in volcanic soil. Chilean Journal of Agricultural Research 70(4):590-595.

Howard, D. D.; M.A. Newman; M. E. Essington and W. M. Percell (2002). Nitrogen fertilization of conservation-tilled wheat. II. Timing of nitrogen application of two nitrogen sources. J. Plant Nutr. 25: 1329-1339.

Johansson, E.; M.L. Prieto-Linde and G. Svensson (2004). Influence of nitrogen application rate and timing on grain protein composition and gluten strength in Swedish wheat cultivars. J. Plant Nutr. Soil Sc. 167:345-350.

Moharram, J. and M. Habib (2011). Evaluation of 10 wheat cultivars under water stress at Moghan (Iran) condition. African Journal of Biotechnology Vol. 10(53), pp. 10900-10905.

Qadir, G.; M.Saeed and M. A. Cheema (1999). Effect of water stress on growth and yield perforrmance of four wheat cultivars. Pak. J. Biological Sci. 1: 236-239.

Rahman, M. A.; M. A. Sufian; M. Saifuzzaman and J. Chikushi (2002). Nitrogen management in ricewheat alternating cropping system and wheat genotype identification preferable to surface seeding condition. J. Fac. Agric. Kyushu Univ., 46: 295-301. 
Rahman, M.A.; M. A. Z. Sarker; M. F. Amin; A. H. S. Jahan and M. M. Akhter (2011). Yield response and nitrogen use efficiency of wheat under different doses and split application of nitrogen fertilizer. Bangladesh J. Agril. Res. 36(2): 231-240.

Rao, A.C.S.; J.L. Smith; V.K. Jandhyala; R.I. Papendick; and J.F. Parr (1993). Cultivar and climatic effects on the protein content of soft white winter wheat. Agron. J. 85:1023-1028.

SAS institute (2008). The SAS System for Windows, release 9.2. Cary NC:SAS institute.
Velasco, J.L.; H. S. Rozas; H. E. Echeverr1 and P. A. Barbieri (2012). Optimizing fertilizer nitrogen use efficiency by intensively managed spring wheat in humid regions: Effect of split application. Can. J. Plant Sci. 92: 847-856.

Zebarth, B. J.; E.J. Botha and H. Rees (2007). Rate and time of fertilizer nitrogen application on yield, protein and apparent efficiency of fertilizer nitrogen use of spring wheat. Can. J. Plant Sci. 87: 709718. 
تاثير مستويات الري وتجزئة السماد الازوتي علي الاتتاجية وكفاءة استخدام الازوت لصنفين من قميح الخبز الأتئ

المهدي عبد المطلب طعيمة، انعام حلمي جلال، السعدي عبد الحميد علي وهويدا عز الاين عبد القادر قسم المحاصيل - كلية الزر اعة - جامعة اسيوط العيأ

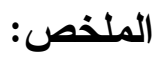

اجريت تجربة حقلية بمزر عة قسم المحاصيل - كلية الزر اعة - جامعــة أسـيوط خــل

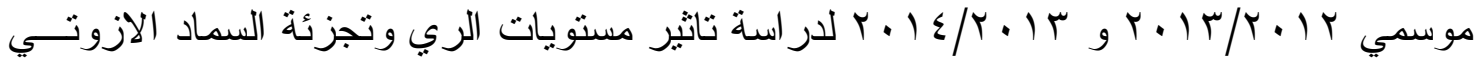
علي الاتتاجية وكفاءة استخدام الازوت لصنفين من قمح الخبز • تم عمل ثلاث تجارب منف صلة

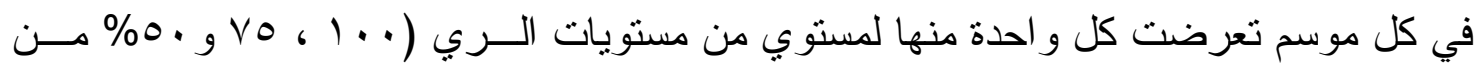
الاحتياج المائي) وصمدت كل تجربة باستخدام القطاعات كاملة العشو ائية بترتيب القطع المنـشقة

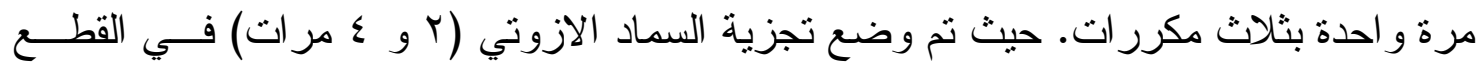
الرئيسية بينما تم وضع الاصناف (جيزة 171 و و سدس () في القطع المنشقة. وكانت اهم النتائج

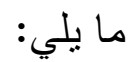

اثز كلا من مستويات الري وتجزئة السماد الازوتي و الاصناف محل الدراسة معنويا علي

كل الصفات المدروسة لكلا الموسمين. كما كان تاثثر تفاعلات الدرجة الاولي وتفاعـل الدرجــة الثانية معنويا علي معظم الصفات محل الدر اسة في موسمي الدراسة. وتم الحصول علي اعلـي

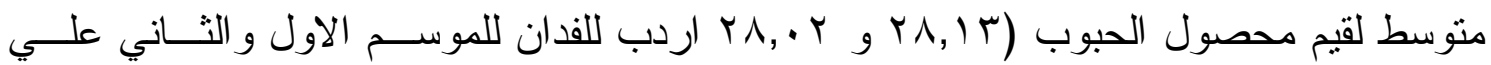

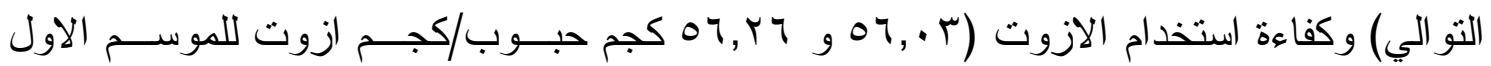
و الثاني علي التو الي) من زر اعة الصنف سدس ا تحت مستوي الري . . 1\% من احتياج الــري وتجزئة السماد الازوتي علي اربع دفعات. 